\title{
Enterprise Debt Financing the Financial Risk and the Countermeasure Research
}

\author{
Dong Hangtao
}

Hangzhou Institute of Commerce,

\author{
ZhejiangGongshang University, Hangzhou Zhejiang 310000
}

\begin{abstract}
With the production and management activities of enterprise scale unceasing expansion, enterprise oneself capital demand on enterprise interior to accumulate and free money has been unable to meet, debt financing under the condition of market economy is the inevitable choice for enterprise to raise funds. Research on debt financing the financial risk and the countermeasure has become one of the most important link in the enterprise management decision. This paper on China's enterprise debt financing the financial risk and the countermeasure research on the debt financing, financial risk system analysis and finishing, supplemented by case analysis, so that the debt financing risk control theory has been improved and sublimation. Can not only enrich the current liabilities financing related theory research, but also for the practice of normative company financing behavior, raise company economic benefits, is conducive to optimizing the financial market of our country construction and system of perfect socialist market economy.
\end{abstract} decision

KEY Words:Debt financing; financial risk; management

\section{INTRODUCTION}

In recent years, with the expansion of the scale of production and operating activities of enterprises, the internal accumulation and free funds of enterprises can't meet the requirements of enterprises. However, debt financing just can effectively meet the requirements of enterprises. It not only has become of the most effective financing ways for enterprises to expand the scale, but also plays an important role in financing decision of enterprises. While having great effect on enterprises, the financing method has potential financial risk. The coming of financial crisis makes many enterprises think over the operation model. Especially some enterprises depending on debts falter in the financial crisis. In 2011, most small and medium-sized enterprises in Wenzhou faced debt crisis and operational difficulties because of huge debt. It is no doubt that the news reminds the enterprise operators. Therefore, a mature enterprise not only needs to operate the equity capital well, but also should have the ability to effectively use the borrowed fund to

reduce the capital cost of enterprises and achieve maximization of corporate profits.

Studying financial risk and decisions of debt financing has become an essential part of business decision of

enterprises. In this sense, the research on financial risk and decisions of debt financing of enterprises in the paper has great theoretical value and realistic significance, which not only enriches the theoretical researches of debt financing, but also important realistic significance to regulate financing behavior, improve the economic benefit of enterprises, optimize the construction of financial market and perfect the socialistic market economy system.

\section{INDEX SYSTEM OF FINANCIAL RISKS OF DEBT FINANCING}

Debt financing risk has direct influence on the safety of business operation, so it is an important link of debt financing risk management of enterprises to evaluate the debt financing risk. Debt financing risk assessment means to establish objective risk assessment index system based on qualitative analysis on debt financing risk to accurately assess debt financing risk, which provides basis for enhancing the management of debt financing risk.

External causes are unavoidable for enterprises, and the enterprises should start from internal causes of influencing factors to prevent from debt financing risk. According to the important factors of debt financing risks mentioned in the paper, the debt condition and operation condition of enterprises is the internal cause of financing risk of enterprises. So the paper uses ratio analysis and the established index system consisting of debt structure index, debt paying ability index and profit ability index. While the debt financing risks of enterprises are evaluated, the indexes should be calculated comprehensively, and the results should be analyzed comprehensively, which can get overall risk evaluation.

\section{A. Debt structure index}

Asset-liability ratio means measuring the debt structure index of financial risk of debt financing means. It is generally used to express the scale of debt of enterprises. In general, asset-liability ratio needs to keep optimal level. For common enterprises, the optimal level of asset-liability ratio is $40 \%-60 \%$, and the formula is as follows.

Asset-liability ratio=total liabilities/total assets $\times 100 \%$ (1)

\section{B. Debt paying ability index}

The indexes measuring debt paying ability of enterprises include current ratio, liquidity ratio, turnover rate of accounts receivable and turnover rate of inventory. The higher the current ratio, the risk the turnover funds of enterprises is, and the greater the paying ability is. The accepted standard in the 
word is $2: 1$. The general standard of liquidity ratio is $1: 1$. The higher the turnover rate of accounts receivable, the better, and the faster the turnover velocity, which means the better the liquidity of funds, the higher the quality. Higher turnover rate of inventory means the faster turnover rate, which can improve the quality of total circulating fund and reduce the loss of detained inventory 2 . The formulas of four indicators are as follows.

Current ratio=current assets/current liability
(2)
Liquidity ratio=liquidity assets/liquidity debt =
(liquidity assets - inventory) /liquidity debt ( )
Turnover rate of accounts receivable=net account of
credit sale/residual of average accounts receivable
(4)

Turnover rate of inventory=selling cost of products/average inventory cost (5)

\section{Profit ability index}

The most direct index measuring the operation and management level of enterprises is profit ability index. The paper selects net interest rate, net profit margin on sales and return on net worth. Higher net interest rate of assets means that the utilization efficiency of assets is higher, and the enterprises achieve good effect for increasing revenue and reduce expenditure and saving fund use. Net profit margin on sales reflects the net profit of the sales, and expresses the income level of sales revenue. The return on net worth is also called net assets returns ratio. The index reflects the rate of return on investment of rights and interests of business owner, and is very comprehensive. The formulas are as follows.

Net return on assets $=$ net profit/average total assets $\times 100 \%$ (6)

Net profit margin on sales $=$ net profits/sales revenuex $100 \% \quad$ (7)

Return on net worth=net profits/average net assets $\times 100 \%$ ( 8 )

\section{CONTROl MEASURES FOR FinANCIAL RiskS OF DEBT} FINANCING

\section{Setting up risk consciousness}

As the important part of the market, the enterprises need to undertake the risks independently. Risk consciousness exists in operation of enterprises. It is difficult to keep crisis awareness at any time. Under the condition that the macroeconomic situation is changeable, the enterprises need to set up risk consciousness, never be satisfied with the current situation, should keep sense of crisis, researches the supplydemand situation of the market and the change of price, concern the economic trends at home and abroad, and establish effective risk prevention mechanism and formulate venture avoiding schemes meeting the current situation of enterprises such as financing to strive for multiple channels, multiple levels and diversification. And the enterprises can keep vital and vigorous and improve themselves to make them competitive in the market economic system.

\section{E. Mastering policies and regulations}

The influence of external policies can't be ignored in the operation environment of enterprises. While pursuing economic interest, the operation of enterprises should meet the established lines, guidelines and policies to achieve the coordination of economic benefit and social benefit. The policies having close relationship with enterprises include fiscal policy, monetary policy and tax policy. The enterprises need to master the regulations of the policies to make the enterprise advance with the times. The policies change, but the enterprises can timely adjust the business strategy and financing strategy, and select the best financing chance to reduce the financial risks of debt financing. For example, the financing arrangement is made according to the change of interest rate, and the interest rate on borrowings changes with the change of government policy and market condition. During the period that interest rate is high level, only shortterm funds in urgent need to be raised. During the transition duration of interest rate from high to low, interest accrual of floating interest rate should be used. When the interest rate is in low level, fund raising is beneficial. During the transition duration of interest rate from low to high, long-term funds should be raised actively and the interest accrual of fixed rate should be used 2 .

\section{F. Moderate debt structure}

The enterprises must accurately master the quantity and grade of debt to meet the precondition that the pre-tax profit margin of equity capital of enterprises should be higher than the interest rate of asset 2. And according to the requirement on funds, financing cost, debt ability and scale of enterprises, the enterprises determine the borrowing debts to avoid blind borrowing. In general, the debt scale of large enterprises is higher, and that of small and medium enterprises is lower.

\section{G. Reasonable asset structure}

Asset structure has great impact on debt structure, so the asset structure of enterprises should be reasonable. Generally speaking, the enterprises that long-term assets have greater proportion should use long-term debt to raise finds. And the enterprises that current assets have greater proportion should use current debt to raise funds. While borrowing funds, the enterprises should fully consider the proportion of short and long term debt to make it rational.

\section{H. Controlling debt paying ability}

The enterprises generally pay the debt in cash. Therefore, firstly, the enterprises must have good asset liquidity to keep sensitivity of working capital of enterprises. Secondly, the enterprises should analyze and measure debt paying ability index, and uses it to predict the debt paying ability as the basis of debt paying plan of enterprises. Lastly, to control the debt paying ability, the enterprises must formulate the repay plan and modify it according to the real paying ability of enterprises, and disperse the financial risks of debt financing to reduce the debt paying pressure. 


\section{Strengthening profitability}

Strengthening profitability of enterprise means to increase the profits of enterprises. Reducing enterprise cost and improving enterprise income is the eternally immutable law of corporate profits. The key is how to reduce enterprise cost and increase the enterprise income to make the enterprises profit. Production technology, management level and human resources are important factors influencing profit of enterprises. For financial risks of debt financing, the enterprises should make scientific decisions, and effectively use borrowed funds to expand reproduction and project investment, which not only can achieve higher return on capital and create greater enterprise value, but also can reduce the risks of debt financing lowest.

\section{J. Keeping financial flexibility}

The enterprises should use slack fiscal policy to keep suitable financial flexibility. On one hand, the enterprises should accumulate some cash reserve when the operation condition is good. When the enterprises have good investment opportunities, they can invest immediately 2 . On the other hand, the enterprises should consider contingent liability, the reason for which is that the contingent liability has potentiality and indetermination, once it becomes the fact, it has impact on cash flow of enterprises and causes debt crisis. So the enterprises should take precautions and make long-range plan to prevent problems.

\section{CONCLUSIONS}

The basic index system of financial risks of debt financing established in the paper is based on debt financing risks, and has pertinence. The involved indexes include the most common index measuring operation condition of enterprises, which are comprehensive. The involved data can be achieved in financial statement of enterprises. The enterprises can achieve the information easily, and timely detect the financial risks of debt financing by daily financial index analysis, which has timeliness.

The index system has defects. For example, indetermination of assets realization and profits forming cash is not included. So in the process of using the index system, the data such as residual cash flow should be combined for analysis.

From the general analysis and empirical analysis on financial risks of debt financing, we can get the measures setting up risk awareness, mastering policies and regulations, making moderate debt structure, making rational debt structure, controlling debt paying ability, strengthening profit ability and keeping fiscal flexibility. Debt financing is mixed blessing for enterprises. While selecting debt financing, the enterprises should be careful and make decisions after understanding the present economic situation and selfrequirements, Under the situation that the economy is not booming, the enterprises should strictly master the degree of debt financing to make debt financing create profits for enterprises and avoid or reduce risks. It is not the task of a stage to prevent from financial risks of debt financing, but is throughout each stage of enterprises. And the enterprises should have a deep understanding on fiscal effect of debt financing and major factors, and flexibly apply control countermeasures of financial risks of debt financing, and refer to the experience and lesson of high-debt enterprises which not only makes the enterprises prevent from financial risks easily, but also makes the enterprises smooth in the road of debt financing.

\section{REFERENCES:}

[1] Yang Deling, Research on new accounting standard and earnings quality [J], Friends of Accounting, 2008(08).

[2] Su Ning, Tian Zhiwei, Li Wei, Empirical research on relationships between debt financing, financial level and product market competition [J], Economic Research Guide, 2008(17)

[3] Zhang Ruili, Li Shaoxuan, Analysis on earnings quality and influencing factors of listed company [J], Communication of Finance and Accounting, 2010(24).

[4] Yan Chenlu, Yang Hui, Accounting conservatism, creditor protection and signature of debt contract [J], Economic Perspective, 2011(04).

[5] Bowen R,E Noreen,J Lacey.Determinants of the Corporate Decision to Capitalize Interest. Journal of Accountancy, 81

[6] Lilien S,V Pastena, Determinants of Intra method Choice in the Oil and Gas Industry. Journal of Accountancy, 1982

[7] Fu Shuhong, Wu Di, Liu Hui, Analysis on financial effect of debt financing [J], Journal of Liaoning Administration College, 2011(08)

[8] Xu Xiumei, Observation on debt financing of enterprises [J], High and New Technology Enterprises in China, 2009(06).

[9] Chen Yan, Analysis on financial risk and precaution of debt financing [J], Knowledge Economy, 2008(07)

[10] Liu Qingxiang, Rao Song, Deng Xinjun, Financial risk and countermeasures of debt financing [J], Journal of Liaoning Administration College, 2008(01)

[11] Su Ming, Analysis on debt financing of enterprises [J], Journal of Sichuan School of Economic Management, 2007(01)

[12] Yao Hui, Analysis on interaction of debt financing and financial lever [J], Times Finance, 2006(05) 